\title{
Tree spacing effects on erosion of soil covered waste rock slopes
}

\author{
A Remaury Université du Québec en Abitibi-Témiscamingue, Canada \\ M Guittonny-Larchevêque Université du Québec en Abitibi-Témiscamingue, Canada \\ J Rickson Cranfield University, UK
}

\begin{abstract}
The management of mine solid waste remains the most important environmental commitment for mine companies. This research project was carried out on the low sulphur waste rock of the Canadian Malartic mine, with the aim of assessing the erosion control effectiveness of different plantation designs on 33\% slopes. Since the mine is located in the boreal forest, the purpose of the project is not only to define the design that provides best soil protection, but also to identify which one best promotes the establishment of trees. Fast-growing poplar may prove to be effective in erosion control on the waste rock slopes because of its fine root development in dry soil and its effect on soil cohesion. The plantation was established in May 2013 and was monitored over two growing seasons with the aim of determining the effect of five treatments (planted trees at three different spacings without hydroseeding; planted trees with hydroseeding; and a control without trees or hydroseeding) on soil loss. Soil loss measurements were related to root morphology, canopy development and understory cover. In the centre of the plantations, soil loss occurred mainly during the spring snowmelt while soil deposition occurred during summer rainfall. During the first two years after planting, the combination of planted trees with hydroseeding showed the best erosion mitigation compared to the control because of its greater herbaceous cover and greater root length density which maximised soil protection. No difference in soil erosion rates was found between the tree spacing treatments. However, the $1 \times 1 \mathrm{~m}$ tree spacing significantly increased root density and tree canopy cover in the second year after planting. Potentially this should be reflected in lower soil loss compared with the other treatments in the third year after planting.
\end{abstract}

\section{Introduction}

Mine solid waste essentially consists of tailings, i.e. crushed ore from which the commercial value has been removed and is transported with water as a slurry. Waste rock comprises all material removed from the mine other than topsoil, subsoil and ore. The management of these two waste materials can be the most important environmental commitment for mining companies (Spitz \& Trudinger 2008). Management of waste rock dumps is important because they are the largest and most visible component of a mining project's footprint. The present study specifically deals with waste rock slopes with low sulphur and metal content that present minimal contamination issues. However, several other environmental issues remain, including land-slips caused by the lack of soil structure and high erodibility of slope forming materials. These mass movements can result in stream sedimentation affecting water quality, and river and stream habitats (Spitz \& Trudinger 2008).

Establishing vegetation on waste rock slopes requires a soil cover and the added substrate can be highly vulnerable to erosion. The term 'erosion' relates to the process of detachment and movement of soil particles and rock. Erosion can aggravate disturbance of the ecological balance by humans and results in negative impacts on water, soil and vegetation (Gray 1996). In particular, erosion can cause soil impoverishment, selectively removing organic matter and topsoil which will create adverse conditions for plant establishment.

When a mine site is located in a woodland zone, revegetation of the waste rock dumps should not only apply a design that allows best soil protection, but should also promote tree establishment. Tree establishment on 
the waste rock soil cover could be promoted by tree planting. The design should include tree species with high growth rates to limit soil erosion and water stress tolerance, given the rapid drainage rates on waste rock slopes. Hybrid poplar is a fast growing species commonly used in plantations on abandoned farmland. However, the nutrient and water needs of hybrid poplars are relatively high compared with others species (Jassal et al. 2013), and weed competition is a major threat during the first years of establishment (Stanturf et al. 2001). Some poplar clones' responses to competition and water stress indicate great potential for revegetation and erosion control on waste rock slopes (Casselman et al. 2006). One study conducted by Blake (1984) showed a wide variability between poplar cultivars concerning stomatal morphology and water-use efficiency. However, the same author explained that under drought conditions, modifications of the shoot: root ratio strongly contributed to tree survival. In the first growing season, hybrid poplar seems to be particularly sensitive to cover crops because of lower water uptake (Shock et al. 2002). Thus, inter- and intraspecific competition could inhibit poplar growth in the low resource environment associated with waste rock slopes, causing stress and mortality, which will affect tree root and canopy development and consequently protection against soil erosion.

Regarding plant interactions, tree growth after planting will depend on the aggressive growth character of the grasses (Hoomehr 2012). Furthermore, tree size and spacing will impact the composition and production of herbaceous species (Scholes \& Archer 1997). Reduction of tree spacing will increase tree height; allocation of carbon to height growth being greater than diameter growth (Benomar et al. 2013). The photosynthetic performance of the understory will depend on the available light as determined by the forest strata density above. Evolution of the vegetation strata influences erosion control. Finally, differences in root development can be observed between herbaceous species, shrubs and trees: grasses will generally be characterised by dense and shallow roots which make them "useful in protecting sites from surficial erosion" (Gray 1996). The root zone of trees tends to be deeper than shrubs (Stokes et al. 2008). The parameter of root length density (RLD), i.e. the length of roots per unit volume of soil, is a crucial parameter for estimating root development (Pierret et al. 2000) and can be related to rates of soil loss. Finally, small diameter roots (1-20 mm) especially contribute to surficial erosion mitigation (Styczen \& Morgan 1995).

The main research objective was to test different plantation designs on waste rock slopes that achieve soil protection against erosion while maximising the establishment of trees. Carried out on low sulphur waste rocks of the Canadian Malartic mine, this research examines the influence of tree spacing and herbaceous cover on the small diameter root, understory and canopy development of a hybrid poplar plantation.

\section{$2 \quad$ Methods and materials}

\subsection{Site description}

The study site is located in the Canadian Malartic mine, in Quebec province and Abitibi sub-province. The Canadian Malartic ore is a mineralised greywacke. The waste rock analysis revealed low sulphur content (less than 1\%), with trace metal concentrations lower than Quebec regulatory thresholds for residential lands. The site belongs to the white birch domain (bioclimatic domain) which occupies the southern portion of the boreal zone (Gauthier et al. 2009). The experimental plots are surrounded by forest stands which include jack pine (Pinus banksiana Lamb.), black spruce (Picea mariana (Mill.) Britton), trembling aspen (Populus tremuloides Michx.), white birch (Betula papyrifera Marsh.), tamarack or eastern larch (Larix laricina (Du Roi) K. Koch, and balsam fir (Abies balsamea (L.) Mill.). In this boreal region, the growing season typically begins in mid-May and ends in early October with a mean temperature during the three warmest months (June, July and August) around $18-19^{\circ} \mathrm{C}$. Average annual temperature is $1^{\circ} \mathrm{C}$, and the average number of frost-free days is 80 . Mean annual precipitation is around $900 \mathrm{~mm}$ (Environment Canada n.d.).

The plantation was established in May 2013 on 33\% slopes (7 m high, west to southwest orientation) covered with $50 \mathrm{~cm}$ of overburden topsoil. The overburden topsoil is a planosol (Food and Agriculture Organization of the United Nations 2015) coming from a swamp area above the pit that had been previously colonised by conifers. The topsoil was stockpiled for 30 to 36 months before use in $7 \mathrm{~m}$ high piles with a 2.5:1 slope. 
The overburden topsoil is characteristic of the Clay Belt of Northeastern Ontario and Northwestern Quebec (Harper et al. 2003). It consists of the uppermost $30 \mathrm{~cm}$ of dark (organic-rich) soil layers (O and A horizons) that had been set aside prior to the excavation of the open pit.

\subsection{Tree planting and hydroseeding}

Hybrid poplars (Populus maximowiczii A. Henry x Populus balsamifera L. (MxB) - clone 915319) were planted on all plots. Trees were locally produced by the Ministère de l'Énergie et des Ressources Naturelles du Québec (MERN). This hybrid was selected for the quality of its response to water stress and the fact that a high proportion of its biomass comes from the roots (Larchevêque et al. 2011a). Indeed, the comparison between two hybrids and a native poplar showed that the $\mathrm{M} \times \mathrm{B}$ clone presents the highest resistance to drought stress (Larchevêque et al. 2011b). As a result, this clone should be preferred because of the rapid drainage of the waste rock slope and the need for erosion control. The trees were clonally propagated one-year-old whips, i.e. 1-m long cuttings, which were planted directly into the soil to a depth of $30 \mathrm{~cm}$. Fertilisation involved the insertion of $15 \mathrm{~g}$ ammonium nitrate (34.5-0-0) and $15 \mathrm{~g}$ triple superphosphate (0-45-0) into a slit made with a spade near the base of each tree (20 cm from the tree and $15 \mathrm{~cm}$ deep).

Trees were planted in the lower half (lowest $12 \mathrm{~m}$ ) of the slope to improve stability (Styczen \& Morgan 1995). In the upper half of the slope, two lines of fast-growing willows were planted at a high shoot density, and hydroseeding was applied on the upper-most $2 \mathrm{~m}$ to limit water run-off and soil erosion. Hydroseeding is considered a useful method to establish grasses by stimulating vegetative growth thanks to a 8-32-16 fertiliser ( $8 \% \mathrm{~N}, 32 \% \mathrm{P}$, and $16 \% \mathrm{~K}$, di- and mono-ammonium phosphates and potassium chloride) $(750 \mathrm{~kg} / \mathrm{ha})$ and the following seed mix, (100kg/ha): Lotus corniculatus (15\%), Trifolium repens (7\%), Trifolium hybridum (3\%), Trifolium pratense (10\%), Avena sativa (11\%), Lolium perenne (12\%), Poa pratensis (15\%), Festuca rubra (15\%), Sorghum bicolor (12\%). The experimental plots of the plantation were established on $50 \mathrm{~cm}$ topsoil covering the waste rocks and separated by a $4 \mathrm{~m}$ wide buffer zones without trees.

\subsection{Experimental design}

The design consisted of 15 experimental plots $(8 \times 12 \mathrm{~m})$ in a randomised complete block design. Depending on the spacing, $16(4 \times 4 \mathrm{~m}$ spacing), $35(2 \times 2 \mathrm{~m})$ or $117(1 \times 1 \mathrm{~m})$ trees were present in each plot. The five treatments indicated in Table 1 and in Figure 1 were randomly distributed in three replication blocks.

Table 1 Treatments description

\begin{tabular}{cccc}
\hline Plot code & Parameters & \\
& Tree spacing (in metres) & $\begin{array}{c}\text { Hydroseeding } \\
\text { Control plot }\end{array}$ & - \\
\hline $\mathrm{T} 2 \mathrm{mH}$ & $2 * 2$ & Yes & - \\
\hline $\mathrm{T} 1 \mathrm{~m}$ & $1 * 1$ & No & - \\
\hline $\mathrm{T} 2 \mathrm{~m}$ & $2 * 2$ & No & - \\
\hline $\mathrm{T} 4 \mathrm{~m}$ & $4 * 4$ & No & $\mathrm{X}$ \\
\hline $\mathrm{T}$ & - & No & \\
\hline
\end{tabular}




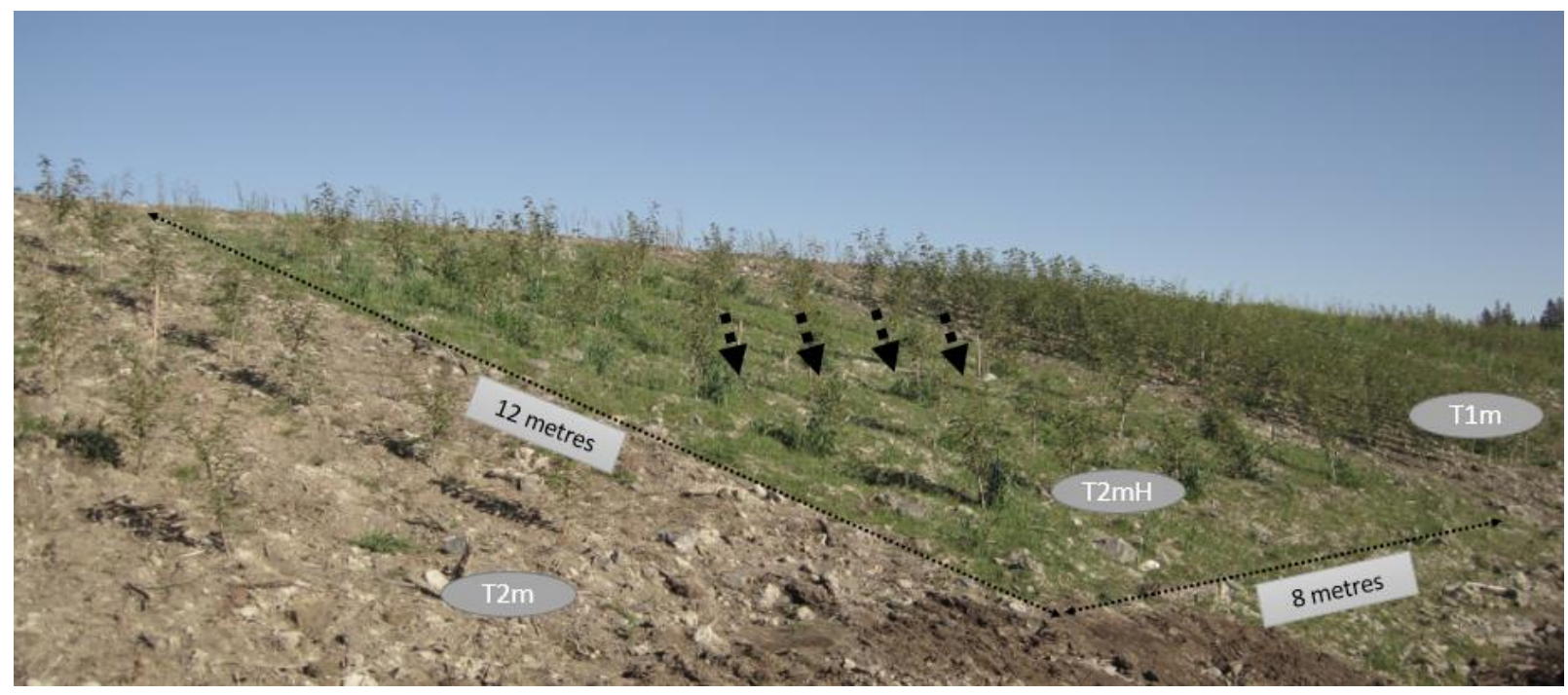

(a)

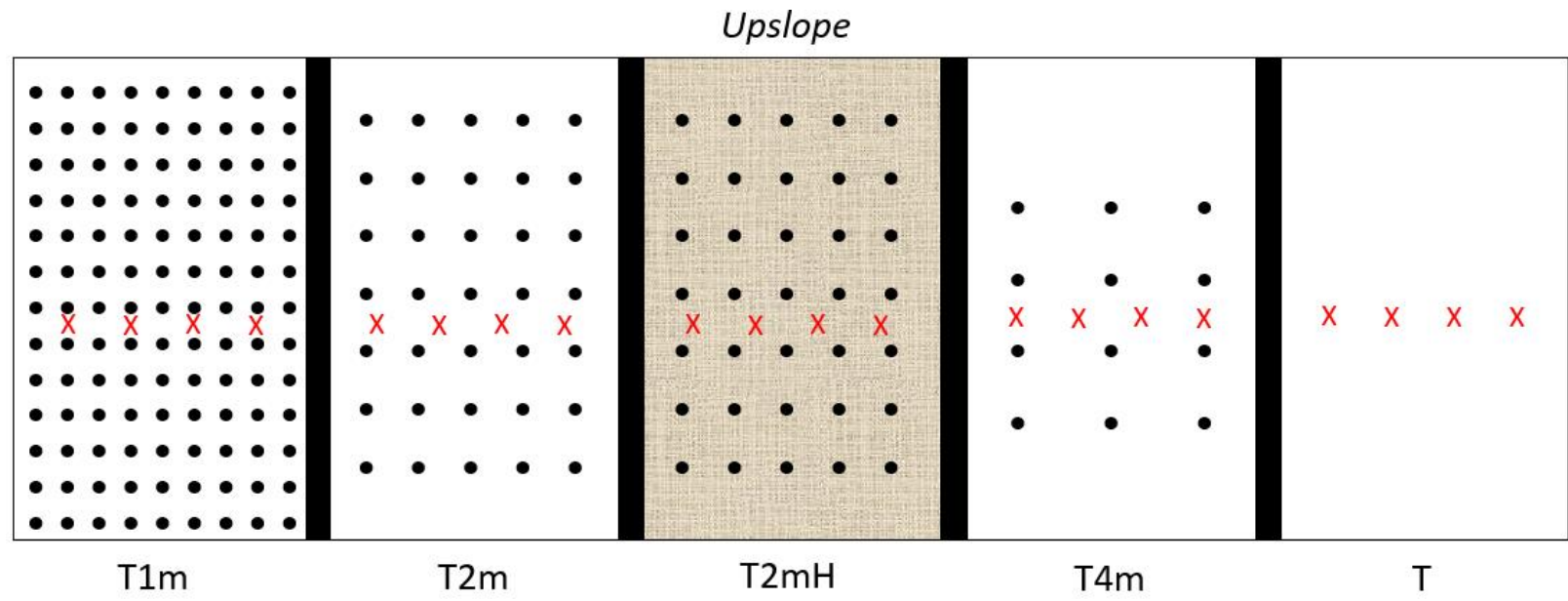

(b)

Figure 1 (a) Plantation photography including three of the experimental plots (T2m, T2mH and T1m) at the first year of the plantation. The black arrows indicate the position of the pins for the erosion measurement. (b) Black dots represent trees, crosses indicate the erosion pins and the vertical black strips show the buffer zones

\subsection{Variables and measurement}

\subsubsection{Soil erosion}

Soil loss was monitored by taking comparative measurements of erosion pins in the spring, summer and autumn. The measurement frequency was a function of the changing seasons; beginning just after all of the snow had melted and finishing just before the first snow. The erosion pin technique allows identification of ground advance and ground retreat (Loughran 1989; Haigh \& Gentcheva-Kostadinova 2002). An erosion pin is a nail or a metal or steel rod inserted into the soil, avoiding any disturbance from the weather or incidental trampling (Haigh 1977). Haigh (1977) recommends installing the pins perpendicular to the slope gradient and notes the precise millimetre-scale accuracy of the method. The pins used in the present project are $70 \mathrm{~cm}$ long metal rods ( $0.6 \mathrm{~cm}$ diameter) inserted 40 to $50 \mathrm{~cm}$ deep into the soil on $4 \mathrm{~m}$ transects (4 pins). Transects were established $6.5 \mathrm{~m}$ downslope from the first line of poplars, approximately in the centre of the $21 \mathrm{~m}$ long slopes, $50 \mathrm{~cm}$ below the closest trees. The degree of erosion was taken to be the average of two measurements taken from the left and the right hand sides of the aboveground part of the pin. The soil loss or gain between the two dates was derived from these measurements. 


\subsubsection{Root development}

The auger sampling method was used to study the root system morphology (Reubens et al. 2007). This method is considered to be an efficient method in assessing root density and RLD in the top soil layer (Reubens et al. 2007).

The core samples were collected around one tree in each plot during each measurement campaign (in the spring, summer and autumn). The tree selected in the spring was located in the plot centre. Then, in the summer and autumn campaign, the tree on the right and left hand sides of the plot centre, respectively, was selected. A collection of eight cores per tree (Figure 2) was taken, based on a design inspired by the method of a Voronoï polygon (Snowdon et al. 2002). Two squares were visualised in the field, one to the right and above the selected tree, and another to the left and below the selected tree. The samples were collected randomly in three areas of each square: one sample from the most distant area from the tree, another from the closest area, and two samples from the intermediate area. Each sample was on a different axis from the plot centre. The auger diameter was $8 \mathrm{~cm}$ (Eijkelkamp). The target core depth was $10 \mathrm{~cm}$ but ranged from 8 to $14 \mathrm{~cm}$. Each core length was noted in order to precisely calculate the corresponding core volume. Where the auger could not penetrate sufficiently deep into the ground, the core was moved to an adjacent location.

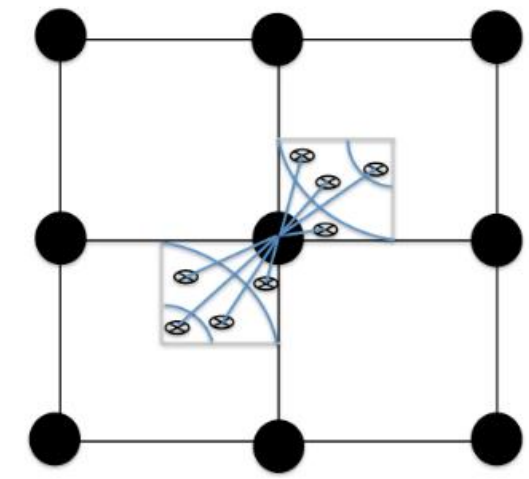

Figure 2 Core sampling method (black dot $=$ trees, dot with cross $=$ core sample)

Finally, for each sample, the roots were washed from the soil and organic residues using tap water and then scanned. Tree and herbaceous plant roots were separated after washing, based on colour and architecture. The roots scans were analysed using the WinRhizo software (Regent Instruments Inc.). This is considered to be the most widely used software in plant stress research (Pang et al. 2011), giving information on root length, area and volume, and classifying these parameters according to the root diameter. The software also calculates the RLD, i.e. the length of roots per unit volume of soil, expressed in $\mathrm{cm} / \mathrm{cm}^{3}$. This is a crucial parameter for estimating root development (Pierret et al. 2000).

Roots were then oven-dried and weighed to obtain root biomass and consequently root density (mass of root/volume of soil units).

\subsubsection{Undergrowth development: biomass and vegetation coverage}

A non-destructive method was used to assess the understory cover and biomass, i.e. the point intercept method (Jonasson 1983). A sharp rod was placed vertically every $10 \mathrm{~cm}$ on the same transect line $(5 \mathrm{~m}$ long, i.e. 50 reading positions), as the one used for the erosion pins. At each rod position, the number of each plant species touching the rod was noted, as well as whether the plant parts were alive or dead, or litter. This measurement was carried out in spring (May) and at maximal understory cover (July). In autumn, only information on species presence or absence was recorded. Destructive sampling of understory biomass was performed once in the growing season (at maximal understory cover) to obtain the relationship between the number of species touching the rod, and biomass by species. Ten sampling squares $\left(1 \mathrm{~m}^{2}\right)$ were selected in which the number of contact occurrences on a $10 \times 10 \mathrm{~cm}$ grid was noted. From this, the coverage and aerial biomass by main plant species or families was derived. 


\subsubsection{Canopy cover}

In the Autumn, data on maximal height, basal diameter and mortality of all trees was collected. All trees were also measured at planting. In the Autumn, maximum tree crown width measurement, toward the sloping hillside $\left(D_{1}\right)$ and normal to the slope $\left(D_{2}\right)$, was taken for six trees per treatment, randomly selected within each plot; these two diameters were used to estimate the canopy cover, assuming the canopy to be an ellipsis (Area $=\pi^{*} D_{1} * D_{2} / 4$ ). The height:diameter ratio was considered as an indicator of the competition effect on tree growth (Becker 1992). Aboveground biomass (leafless) was estimated from the specific allometric equation: $\mathrm{W}=0.28 \mathrm{DBH}^{1.79}$ where $\mathrm{w}$ is aboveground biomass ( $\mathrm{kg}$ dry mass) and $\mathrm{DBH}$ (Diameter Breast Height) is the tree diameter $(\mathrm{cm})$ at breast height $(1.3 \mathrm{~m})$ (Benomar et al. 2012). This model was constructed from the harvesting of 18 trees, 6 years after planting of a hybrid poplar clone ( $P$. maximowiczii $A$. Henry $x P$. balsamifera L.) (MB915 clone) in the boreal region of Abitibi Temiscamingue.

\subsection{Statistical analysis}

At each date, a descriptive statistical analysis was performed and the normal distribution of the data was verified. A one-way analysis of variance was carried out in order to identify if a significant difference among the treatments occurred for the studied parameters. These were: erosion $(\mathrm{cm})$; root density $\left(\mathrm{g} / \mathrm{m}^{3}\right)$; $\operatorname{RLD}\left(\mathrm{cm} / \mathrm{m}^{3}\right)$; understory biomass $(\mathrm{g})$ and percentage cover (\%); poplar canopy cover percentage (\%); and height, diameter and volume of the trees. The blocks and the treatments were submitted to a regression, i.e. the treatment as a fixed effect and the block as a random effect, in order to identify which parameters were significantly affected. A pairwise comparison (Bonferroni) allowed testing of the null hypothesis of no significant difference. Finally, a multiple regression was performed in order to identify the significant variables affecting soil loss. Prior to testing the regression models, the correlations between variables were examined.

\section{Results and discussion}

In the following text and figures, the treatments are coded thus: ' $T 1 \mathrm{~m}$ ', ' $T 2 \mathrm{~m}$ ' and ' $\mathrm{T} 4 \mathrm{~m}$ ' represent tree spacings of 1,2 and $4 \mathrm{~m}$, respectively, and ' $\mathrm{H}$ ' indicates whether the treatment received hydroseeding. The ' $T$ ' treatment corresponds to the control plot.

\subsection{Soil erosion}

Since the first erosion pin measurement in July 2013, two different changes in soil surface level could be identified: soil erosion during the spring snowmelt (between October 2013 and June 2014), and soil deposition during the summer rainfall (between June and October 2013 or June and October 2014) (Figure 3). So, for the analysis the data were separated into two time periods associated with either soil loss or soil deposition.

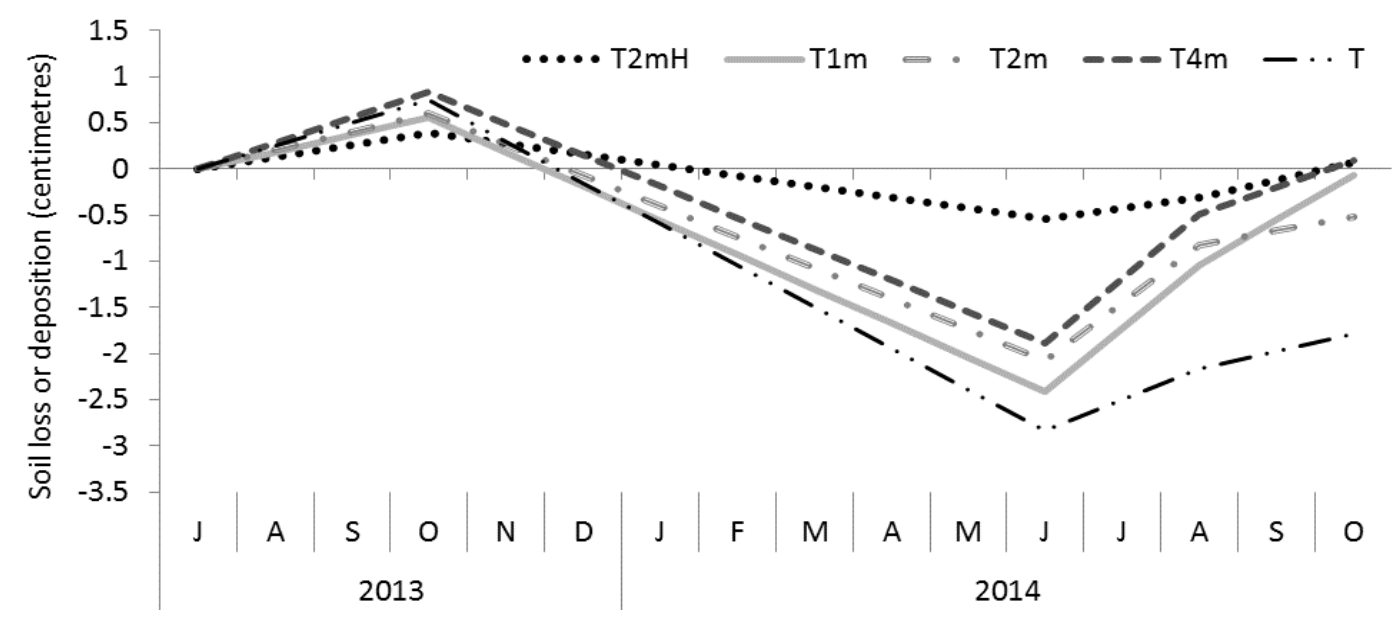

Figure 3 Mean soil loss (-) and deposition (+) (in cm) at the pin level between July 2013 and October $2014(n=4)$ 
The soil loss difference between $\mathrm{T} 2 \mathrm{mH}$ and all the treatments was significant during the spring snowmelt $(p<0.001)$. The treatment $\mathrm{T} 2 \mathrm{mH}$ showed the lowest variation of soil loss or deposition during the first year after plantation. On the other hand, the control treatment $(T)$ suffered the highest rate of soil loss and had the worst performance at the end of the monitoring period. The three other treatments $(\mathrm{T} 1 \mathrm{~m}, \mathrm{~T} 2 \mathrm{~m}$ and T4m) presented intermediate soil losses compared to $\mathrm{T} 2 \mathrm{mH}$ and $\mathrm{T}$ (Figure 4).

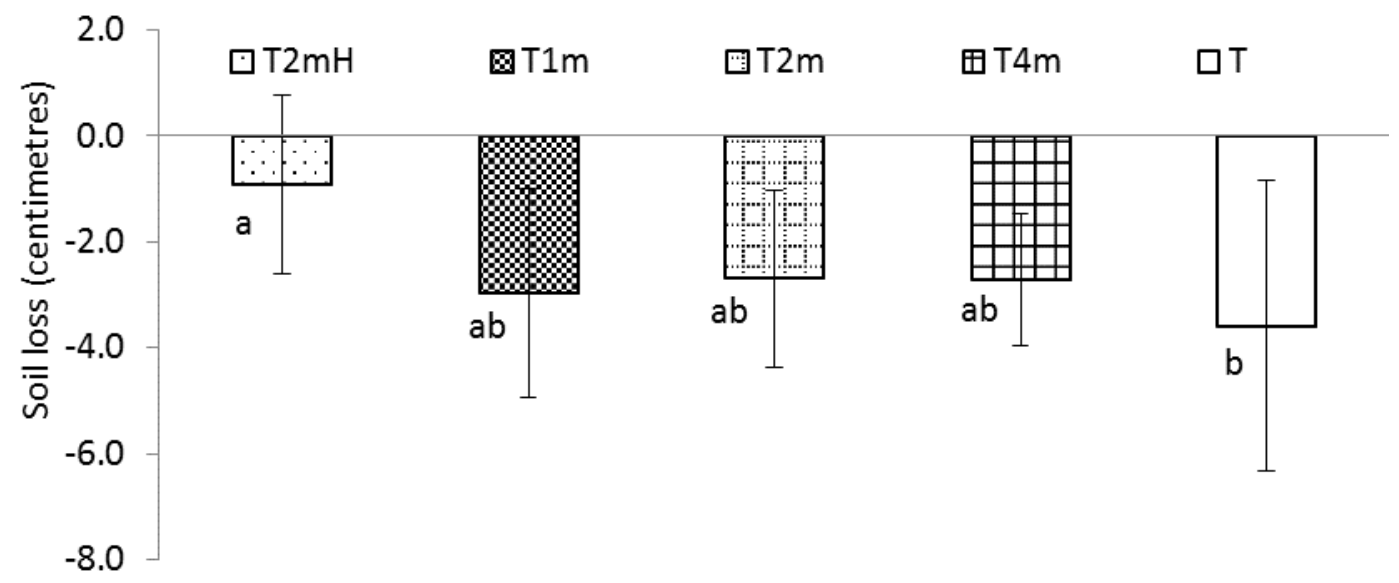

Figure 4 Mean soil loss (in $\mathrm{cm}$ ) during the 2014 spring snow melt. $(n=12)$. Bars denote SE. Means that do not differ at the 0.05 level are noted with the same letter $(a<b)$

A visual inspection of the experimental plots did not reveal any apparent signs of a change in soil surface level. Indeed there was no occurrence of rill or gully erosion and the changes in soil surface level were quite small and uniform at the plot level. The erosion pin method is recognised as being well suited to these study conditions and to meet the stated research objectives. However, it should be noted that the experimental design and this point method of soil surface monitoring can only give comparative erosion estimates between treatments. A higher number of erosion pins and/or other complementary methods such as silt fences or groundbased Lidar could have assessed erosion/deposition rates in a more quantified way. These methods could not be implemented due to technical reasons, i.e. low erosion rates and the high density of herbaceous cover. There were other logistical reasons, including the need to restrict access on the plots and the obligation to share the field with other research projects and the Canadian Malartic mine staff.

Due to the limitations of space and the number of plots with the same slope conditions (soil, exposure, length and degree), it was not possible to design a completely balanced experiment. Only one hydroseeded treatment was used, and it is recognised that this could lead to some potential limitations in the interpretation of the results. In any case, the present study aims to determine which tree spacing is more beneficial to both tree development and erosion control, rather than assessing the effect of hydroseeding on erosion. Indeed the hydroseeding treatment was only chosen to demonstrate how an intense herbaceous competition can influence tree development and soil erosion rates. The other variables analysed allowed this assessment.

Despite these acknowledged limitations, the results show some clear tendencies. The first measurement campaign (September 2013 to October 2014) allowed an assessment of how the vegetation development influenced the soil loss associated with snow melt. Other measurements in summer 2013 and 2014 showed deposition taking place. This last observation could characterise a slower erosion dynamic at the top of the slope, with deposition of eroded material over the rest of the slope. However this could also be due to others factors: soil expansion caused by compression rebound, freeze-thaw processes, mineral slaking, moisture swell, and roots expansion (Fields-Johnson et al. 2009). 


\subsection{Root morphology parameters}

The RLD was the most useful parameter to study the differences between the treatments during the first year of the plantation. By contrast, average root diameter and root biomass were similar among treatments. Sampled roots with a diameter lower than $2 \mathrm{~mm}$ accounted for $93.74 \%$ of the total root length.

Poplar RLD was significantly higher in T1m than in all the other treatments at all sampling dates (Figure 5). The seasonal variation was also greater for this treatment, particularly between July and October 2014. The Poplar RLD results for the three other treatments were comparable. The treatment $\mathrm{T} 2 \mathrm{mH}$ showed a significantly greater herbaceous RLD than for the other treatments.

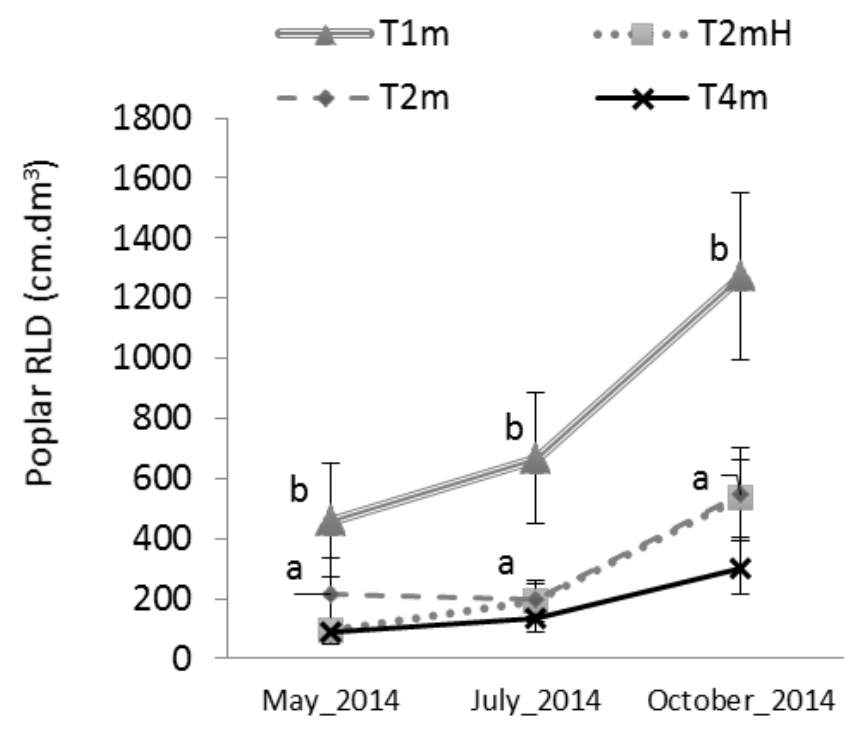

(a)

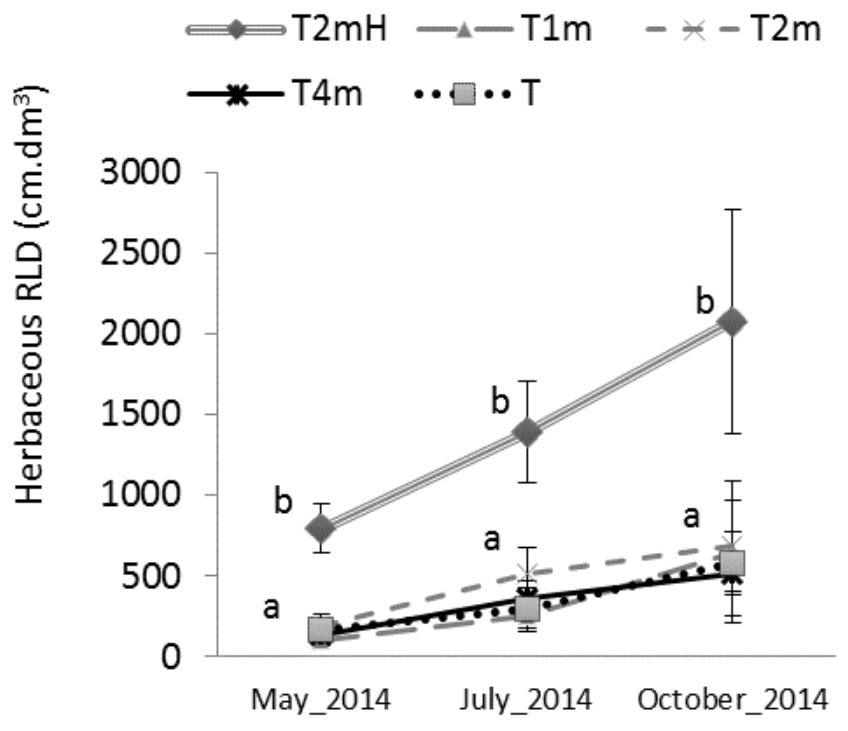

(b)

Figure 5 (a) Mean poplar and (b) Herbaceous RLD by treatment and period ( $n=24)$. Bars denote SE. Means that do not differ at the 0.05 level are noted with the same letter $(a<b)$

$\mathrm{T} 2 \mathrm{mH}$ presented the greatest total RLD in all the periods; the herbaceous roots represented 90\% (May 2014) to $80 \%$ (October 2014) of the total RLD. The T1m treatment had the second best total root development, thanks to the contribution from the many closely spaced trees, but this decreased over time $(81,73$ and $66 \%$ respectively, in May, July and October 2014). Finally, the total RLD declined with tree spacing (T2m versus $\mathrm{T} 4 \mathrm{~m}$ ) and the treatment T showed the lowest RLD representing $22 \%, 29 \%, 47 \%$ and $70 \%$ of the T2mH, T1m, $\mathrm{T} 2 \mathrm{~m}$, and T4m RLDs respectively. Finally, $\mathrm{T} 2 \mathrm{mH}$ and $\mathrm{T} 1 \mathrm{~m}$ had, in October 2014, a significantly lower fine root proportion, i.e. length of the roots with a diameter less than $2 \mathrm{~mm} /$ Total root length, compared to other treatments (results not shown).

The poplar root system should continue to increase in the $11 \mathrm{~m}$ treatment during the third year of planting and could further improve the soil cohesion (Friend et al. 1991). Marino and Gross (1998) explained that, in the case of high competition, poplar may invest more energy to root growth. Intra- or interspecific competition could increase root biomass of the used clone because of its adaptation to water stress (Larchevêque et al. 2011b). Finally, Friend et al. (1991) showed that in high density planting ( 1 $1 \mathrm{~m}$ spacing) "horizontal root spread was approximately sixfold larger than crown radius" and each root system overlapped with one another.

The tree and herbaceous root contributions, respectively, will change over time. Indeed, T1m RLD was at first essentially composed of tree roots but the proportion of herbaceous roots constantly increased. By contrast, the herbaceous roots in the $\mathrm{T} 2 \mathrm{mH}$ treatment were partially replaced by tree roots over time. This evolution showed how the colonising plants and tree growth may modify the occupation of soil by roots and how the difference between the treatments will be subject to change throughout the development of the plantation. 


\subsection{Vegetation cover and tree growth}

\subsubsection{Poplar cover}

Poplar cover depended on the spacing; the lowest space between the trees gave the highest projected canopy cover (Figure 6). However, the comparison between $\mathrm{T} 2 \mathrm{~m}$ and $\mathrm{T} 2 \mathrm{mH}$ highlighted the significant negative effect of hydroseeding on the aerial development of the trees.

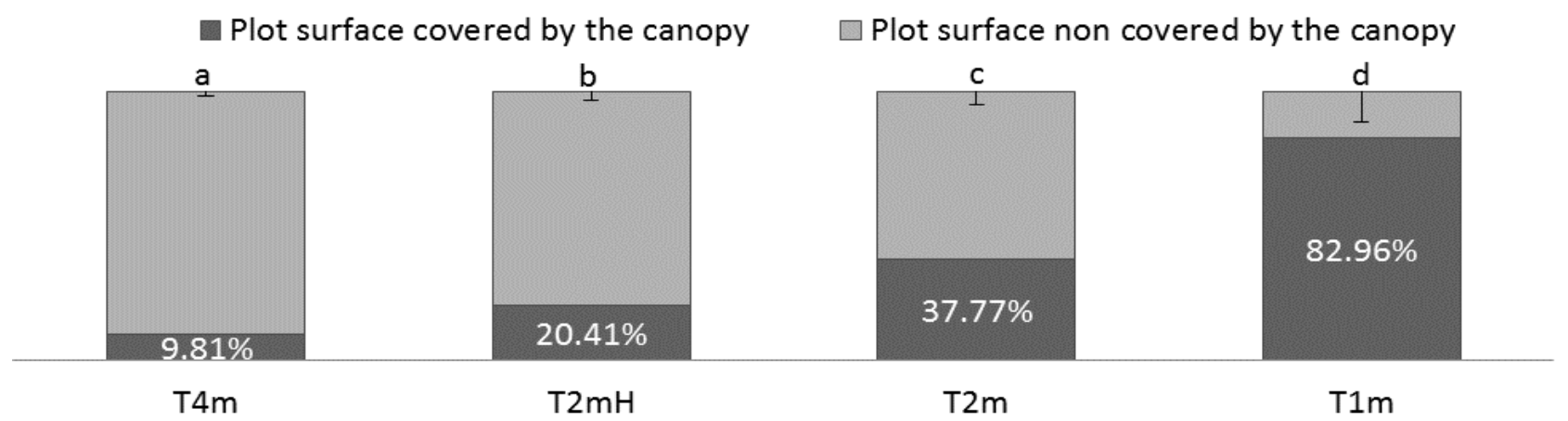

Figure 6 Mean estimation of Poplar cover in per cent. $(n=12)$. Bars denote SE. Means that do not differ at the 0.05 level are noted with the same letter $(a<b<c<d)$

The average canopy diameter data demonstrated the difference between the two, $2 \mathrm{~m}$ spacing treatments; the average canopy diameter of $\mathrm{T} 2 \mathrm{mH}$ was lower than $\mathrm{T} 2 \mathrm{~m}$, which had the highest canopy diameter of all the treatments. The $\mathrm{T} 1 \mathrm{~m}$ and $\mathrm{T} 4 \mathrm{~m}$ treatments presented similar canopy diameters, despite the large difference in tree spacing (results not shown).

\subsubsection{Tree growth and survival}

Tree height was greater for $\mathrm{T} 1 \mathrm{~m}$ and $\mathrm{T} 2 \mathrm{~m}$ and lower for $\mathrm{T} 4 \mathrm{~m}$ and $\mathrm{T} 2 \mathrm{mH}$ (Figure 7). The two extreme spacings used in the study, i.e. the T1m and T4m treatments, presented the highest and lowest height/diameter ratio (H/D) among the four treatments respectively (Figure 8). Combining the data on canopy diameter and aboveground biomass to the height growth and H/D provided evidence of the differences between $T 2 m$ and $\mathrm{T} 2 \mathrm{mH}$ trees. $\mathrm{T} 2 \mathrm{mH}$ is characterised by a lower height growth, $\mathrm{H} / \mathrm{D}$ and aboveground biomass than $\mathrm{T} 2 \mathrm{~m} ; \mathrm{T} 2 \mathrm{mH}$ canopy diameter was the lowest of the four treatments and much lower than $T 2 \mathrm{~m}$.

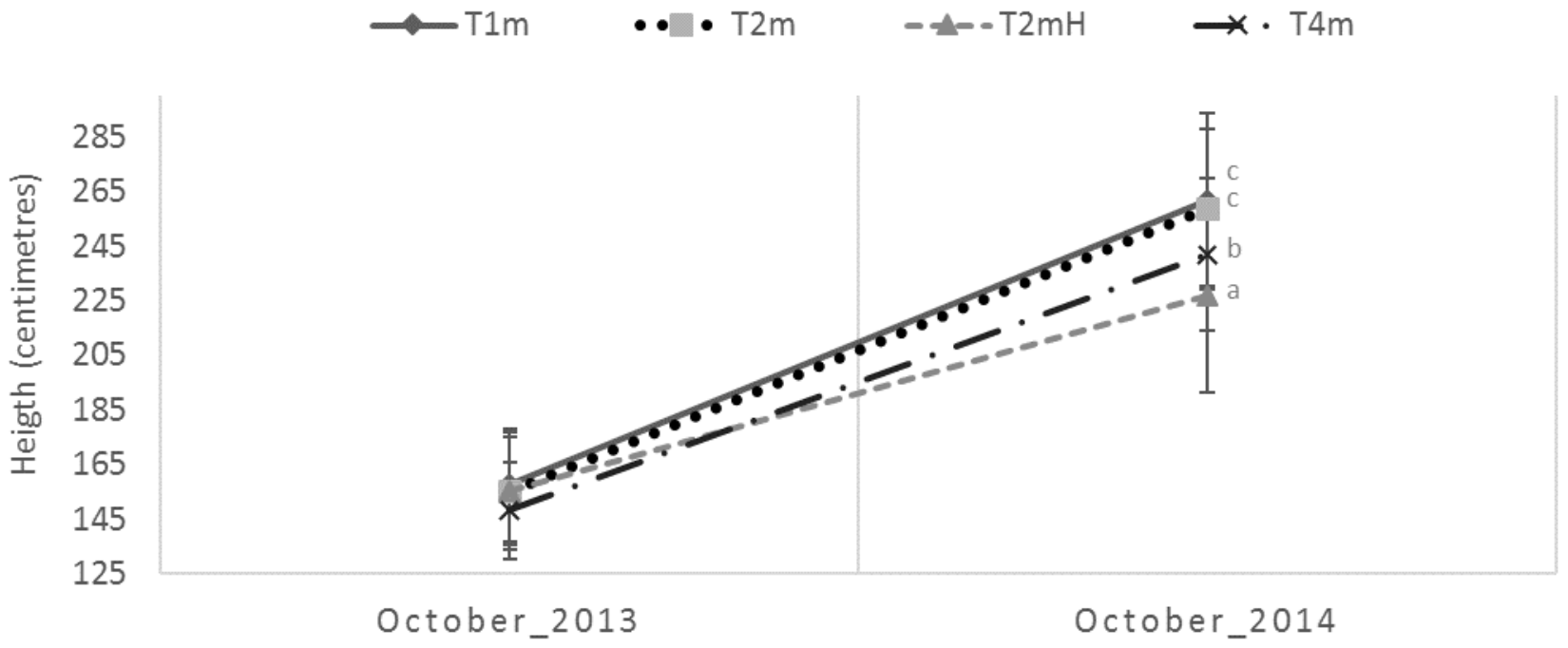

Figure 7 Mean Poplar height growth (in $\mathrm{cm}$ ) between the first year and second year of planting ( $\mathrm{n}>35)$. Means that do not differ at the 0.05 level are noted with the same letter $(a<b<c)$ 


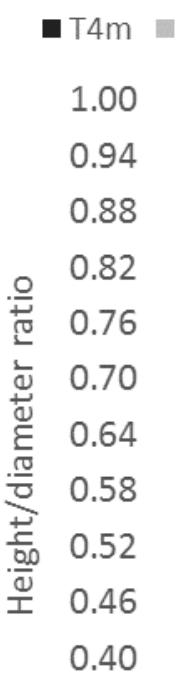

0.40

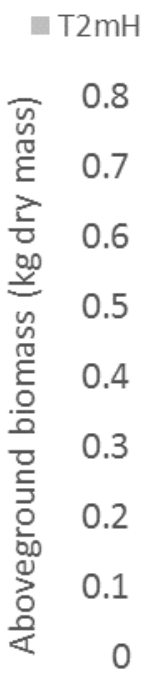

(a)

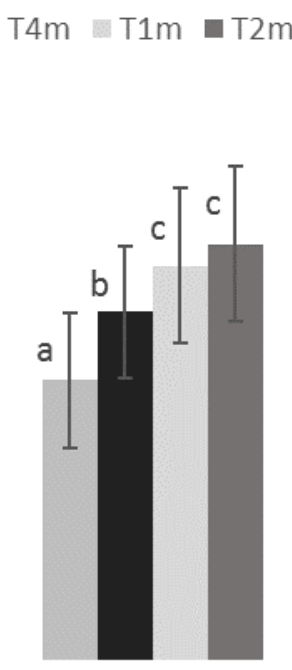

(b)

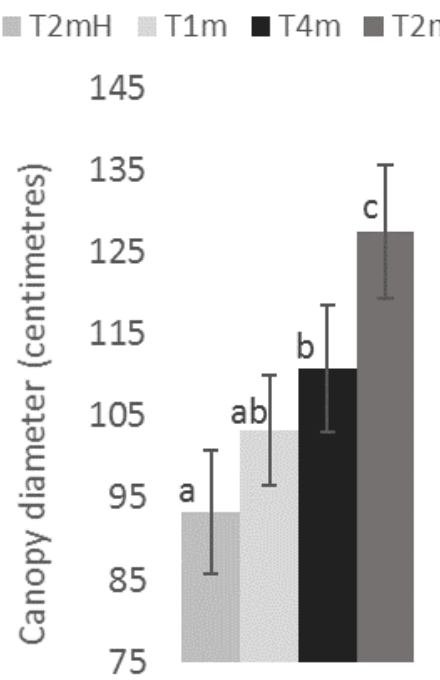

(c)

Figure 8 (a) Mean Poplar height/diameter ratio, (b) aboveground biomass and (c) canopy diameter at the second year of planting $(n>35)$. Means that do not differ at the 0.05 level are noted with the same letter $(a<b<c)$

One year after planting, the tree mortality was $0 \%$. Finally, all these results demonstrated (Table 2):

- For T1m: a fast vertical aerial growth and greater superficial root length.

- For T2m: a fast and balanced aerial growth.

- For T2mH: a reduced aerial growth.

- For T4m: a slow and balanced aerial growth.

Table 2 Treatment comparison (highest results in black, lowest in pale grey)

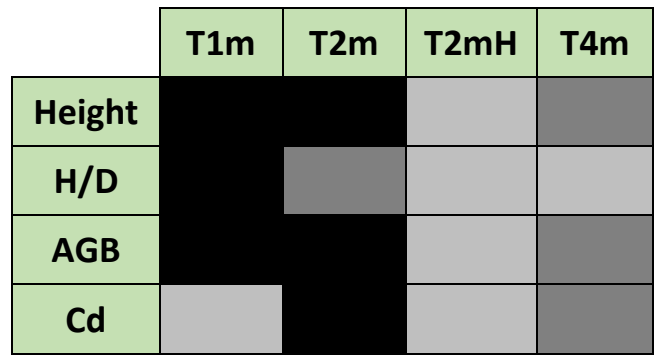

$\mathrm{H} / \mathrm{D}=$ height diameter ratio, $\mathrm{AGB}=$ Aboveground biomass, $\mathrm{Cd}=$ Canopy diameter

\subsubsection{Understory development}

During the first year after planting, the trees in the hydroseeding treatment provided higher soil protection, due to the combination of trees with fast-growing herbaceous agronomic species. By contrast, the control plot T was less protected before the period of snowfall (September 2013) (Figure 9). 

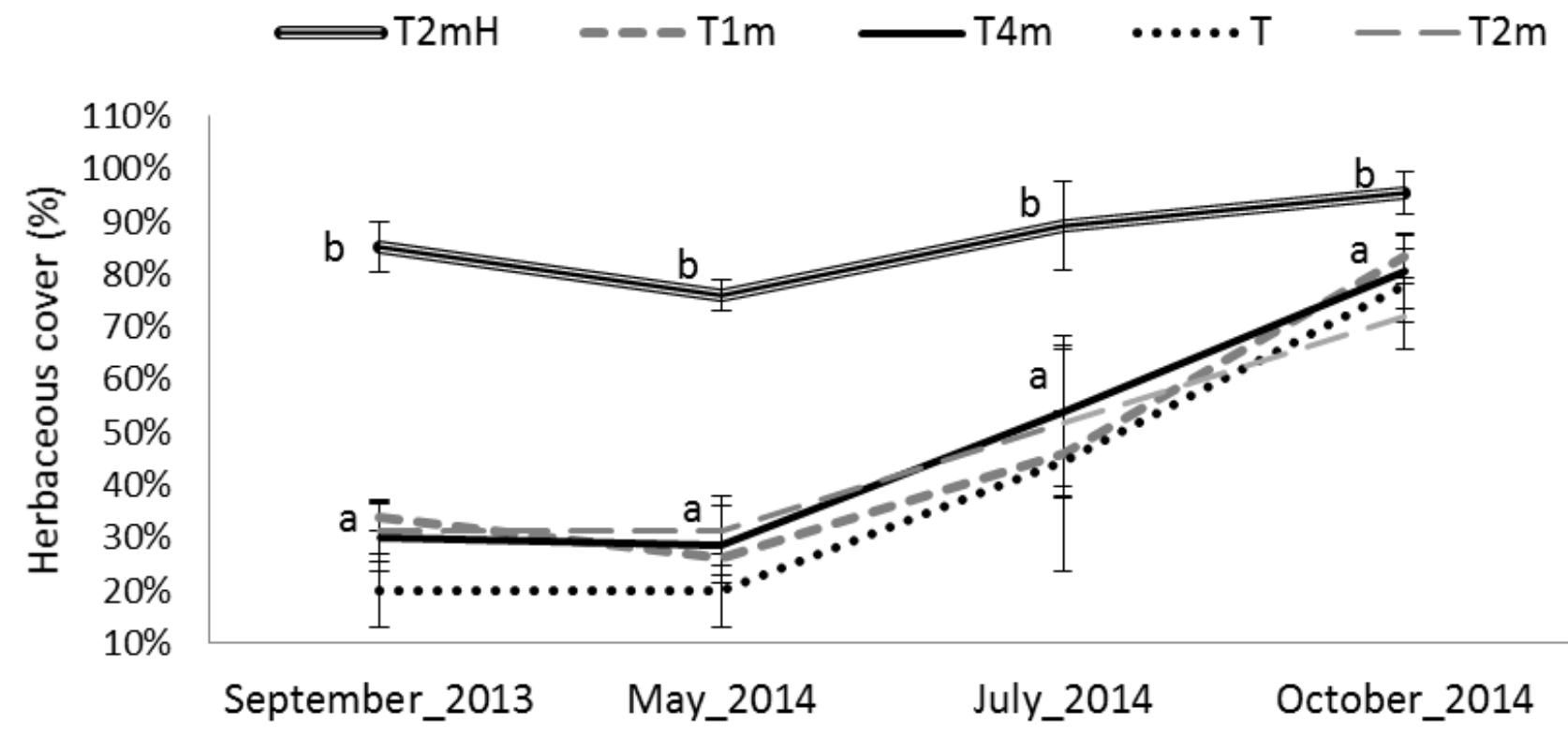

Figure 9 Mean herbaceous cover development in per cent since planting ( $n=3$ transects). Means that do not differ at the 0.05 level are noted with the same letter $(a<b)$

The development of the herbaceous cover from naturally colonising species during 2014 resulted in a comparable cover for all the treatments at the end of the period. However, two types of herbaceous cover were observed: 1) the hydroseeded mix, and 2) the colonising plants. Indeed the herbaceous biomass development was very much higher in $\mathrm{T} 2 \mathrm{mH}$ plots than the other treatments (Figure 10). This result helped to identify factors of cover quality (foliage density), as well as nutrient demands and extraction.

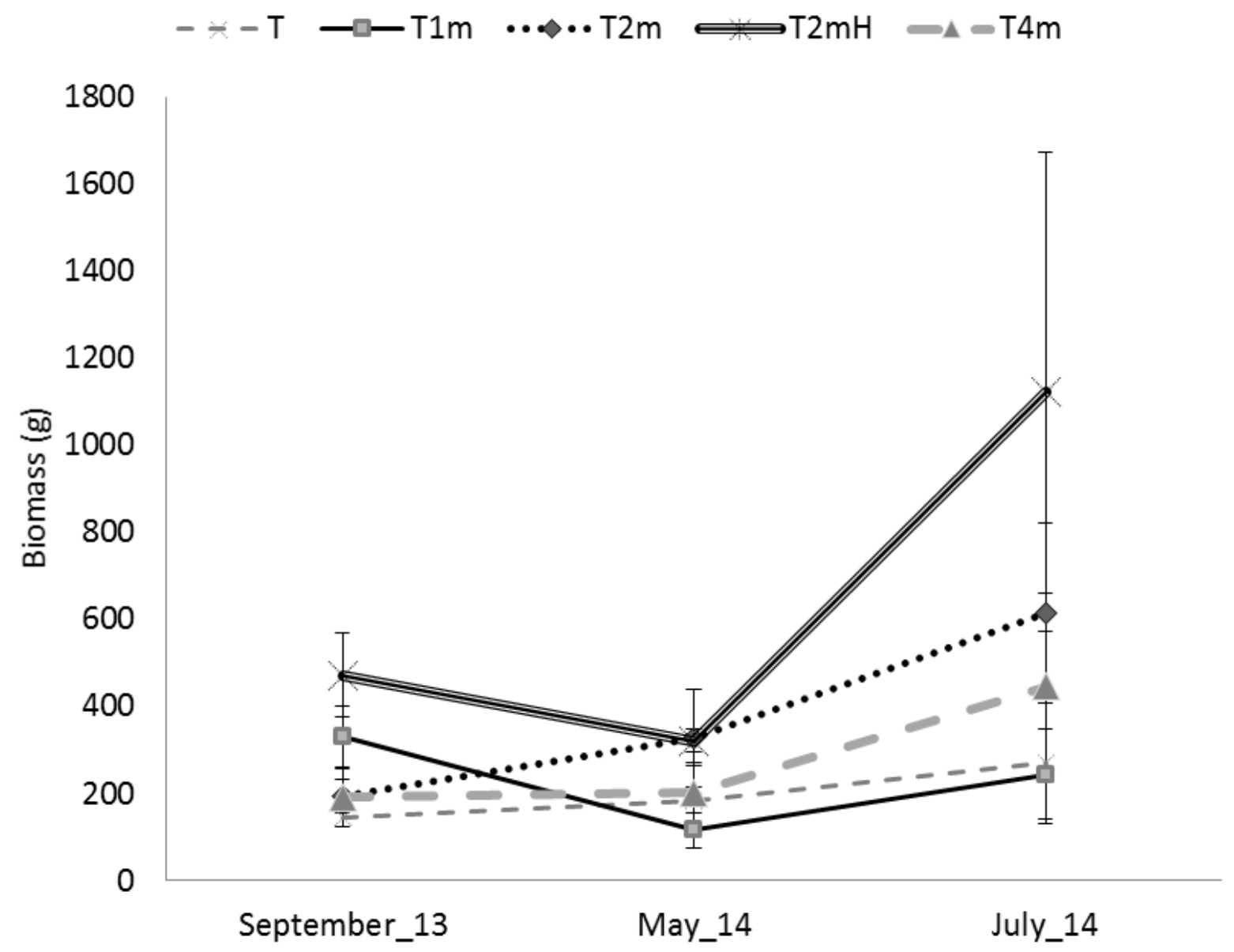

Figure 10 Mean herbaceous biomass development since planting ( $\mathrm{n}=3$ transects) 


\subsection{Influence of RLD and vegetation cover on erosion}

The control plot was the treatment with the highest erosion rate and, at the same time, the treatment with the lowest root development and vegetation cover. On the contrary, the treatment with the lowest erosion rate, i.e. $\mathrm{T} 2 \mathrm{mH}$, is characterised by the highest root development and the greatest vegetation cover thanks to the understory hydroseeded plants. It should be noted that hydroseeding was not used on all spacing treatments, so this finding is based on an incomplete experimental design (as dictated by limited experimental area of similar site (slope) conditions).

The data showed significant effects of the two treatments with the highest competition level on root development; one explained by the high understory coverage (interspecific competition; $\mathrm{T} 2 \mathrm{mH}$ ); and the other by the close tree spacing (intraspecific competition) $(\mathrm{T} 1 \mathrm{~m})$. Soil cohesion created by good root development limited soil loss; consequently of the treatments tested, those two treatments should be the most efficient during the first years of planting for erosion control (Stokes et al. 2008). This fact is already verified for the $\mathrm{T} 2 \mathrm{mH}$ treatment but the current data do not permit drawing cause and effect relations between root development and erosion control in the $\mathrm{T} 1 \mathrm{~m}$.

The T1m and T2m treatments showed the highest growth rate (height) in 2014, possibly due to the greater tree spacing and the resource allocation strategy of the plants. Nilsson (1994) found that height was positively correlated with stand density. Hansen and Baker (1979) demonstrated that the mean annual aboveground biomass increment is greater in closer spacing treatments during the first years of planting for poplar stands. Strong and Hansen (1993) explain that these results are not valid in the long-term because of the high competition between trees and implications of this regarding mortality rate. A short distance between the trees involves a limited access to photosynthetic radiations, high water and nutrient competition and a strategy to concentrate effort in height growth. Larger spacings with fewer trees allow a more balanced distribution of the energy for lateral, longitudinal height and root growth; this intermediate behaviour in terms of development could explain why $\mathrm{T} 4 \mathrm{~m}$ tended to be the second best treatment in terms of erosion control results.

On the other hand, of the treatments tested, $\mathrm{T} 2 \mathrm{mH}$ showed the slowest development of tree aerial parts which leaves open the question of the conditions where hydroseeding is combined with tree plantation e.g. including a lower density of seeds and/or not using competitive grasses, but only leguminous plants. Fields-Johnson et al. (2009) demonstrated that a tree and non-competitive groundcover mix caused less erosion than a conventional mix. However, the aggressive growth of the hydroseeded plants would be responsible for the best soil stability in $\mathrm{T} 2 \mathrm{mH}$ (Pohl et al. 2009); the RLD of the grasses are the first contributor to erosion control during the first year after planting.

Finally, vegetation cover density and canopy architecture all depend on tree spacing, understory structure and species composition. These factors will have an influence on rainfall interception and rainsplash processes. Canopy interception transforms the raindrop size, through leaf storage, coalescence and drip processes, as well as effects on fall height and drop velocity (Armstrong \& Mitchell 1987). Kittredge (1948) explained that interception of rainfall in a hardwood forest was proportional to canopy density. Moreover, DeBell et al. (1996) found that wide tree spacings accumulated a greater proportion of biomass in the branches. T4m had the second best lateral growth but did not compensate efficiently for the incomplete plot cover that resulted from the extreme spacing. The $\mathrm{T} 2 \mathrm{~m}$ treatment showed higher canopy diameter and aboveground biomass in October 2014. Of the treatments tested, this spacing created the most suitable aerial tree development for soil protection, but not at the belowground level (i.e. root superficial development).

\section{Conclusion}

Above- and belowground development of vegetation should be considered as one of the determining factors in the implementation of the most efficient and sustainable erosion control plantation design. The eroding behaviour of waste rock soil covers can be related to both root and aboveground biomass development for 
different planting designs. Even if the aboveground data is considered to be too premature to determine a stand evolutionary pattern, tree growth analysis can determine which design might ensure the best soil protection in the first two years after plantation, and beyond. With regard to root development, erosion intensity was clearly associated with the herbaceous RLD.

Tree and understory development will change vegetation effects on erosion rates over time. The third year results (not included in this first phase of the field work), might bring an overview of tree spacing effects on erosion by characterising the evolution of the RLD, as well as the fine root density of the different treatments. Aboveground biomass and RLD differences between $\mathrm{T} 2 \mathrm{mH}$ and $\mathrm{T} 2 \mathrm{~m}$ already allow us to discern the future consequences on vegetation mortality and stand dynamics, due to herbaceous and tree competition effects. Indeed, tree development was inhibited by hydroseeded herbaceous species which could result in a lower tree cover for $\mathrm{T} 2 \mathrm{mH}$. This point is especially important according to the mine closure legal obligation which includes woodland rehabilitation. Lastly, of the treatments tested, the T1m treatment suggests the best erosion control abilities thanks to a higher RLD and tree cover from the third year of planting. At the longer term, tree larger and deeper roots could contribute better to slope reinforcement than more shallow and thin herbaceous roots, if their roots are able to develop in waste rocks under the covering soil. This potential benefit of tree plantation in waste rock slopes should be further investigated.

The limits of the study include the accuracy of the erosion measurement at the plot level. Indeed point-based erosion pin measurements can be difficult to extrapolate to the whole plot. As a result, the impact of rainfall on the soil is difficult to interpret accurately. The addition of 4 pins per plot in the upper part of the slope will improve the analysis of erosion/deposition rates. Other studies should use complementary methods for describing the erosion dynamics with more accuracy. More direct methods such as collecting the eroded soil in troughs and tanks or using groundbased Lidar methods would also allow quantitative estimates of erosion rates. The control of the herbaceous cover with herbicide would encourage erosion processes and allow tree spacing effects to be studied in isolation.

\section{References}

Armstrong, CL \& Mitchell, JK 1987, 'Transformations of rainfall by plant canopy', Transactions of the ASAE-American Society of Agricultural Engineers, vol. 30, no. 3, pp. 688-696.

Becker, M 1992, 'Deux indices de compétition pour la comparaison de la croissance en hauteur et en diamètre d'arbres aux passés sylvicoles variés et inconnus', Annales des Sciences Forestières, vol. 49, pp. 25-37.

Benomar, L, DesRochers, A \& Larocque, GR 2012, 'The effects of spacing on growth, morphology and biomass production and allocation in two hybrid poplar clones growing in the boreal region of Canada', Trees, vol. 26, no. 3, pp. 939-949.

Benomar, L, DesRochers, A \& Larocque, GR 2013, 'Comparing growth and fine root distribution in monocultures and mixed plantations of hybrid poplar and spruce', Journal of Forestry Research, vol. 24, no. 2, pp. 247-254.

Blake, TJ, Tschaplinski, TJ \& Eastham, A 1984, 'Stomatal control of water use efficiency in poplar clones and hybrids', Canadian Journal of Botany, vol. 62, no. 7, pp. 1344-1351.

Casselman, CN, Fox, TR, Burger, JA, Jones, AT \& Galbraith, JM 2006, 'Effects of silvicultural treatments on survival and growth of trees planted on reclaimed mine lands in the Appalachians', Forest Ecology and Management, vol. 223, pp. 403-414.

DeBell, DS, Clendenen, GW, Harrington, CA \& Zasada, JC 1996, 'Tree growth and stand development in short-rotation Populus plantings: 7-year results for two clones at three spacings', Biomass and Bioenergy, vol. 11, no. 4, pp. 253-269.

Environment Canada n.d., National climate archives, viewed 31 October 2015, http://climate.weatheroffice.ec.gc.ca/index.html

Fields-Johnson, C, Zipper, CE, Burger, JA \& Evans, DM 2009, 'First year response of mixed hardwoods and improved American chestnuts to compaction and hydroseed treatments on reclaimed mine land', Proceedings of the 2009 National Meeting of the American Society of Mining and Reclamation, Lexington, pp. 20-34.

Food and Agriculture Organization of the United Nations 2015, 'World reference base for soil resources 2014 - International soil classification system for naming soils and creating legends for soil maps', World soil resources reports, viewed 16 November 2015, http://www.fao.org/3/a-i3794e.pdf

Friend, AL, Scarascia-Mugnozza, G, Isebrands, JG \& Heilman, PE 1991, 'Quantification of two-year-old hybrid poplar root systems: morphology, biomass, and (14)C distribution', Tree Physiology, vol. 8, pp. 109-119.

Gauthier, S, Gosselin, J, Grondin, P, Lavoie, C, Leduc, A, Morin, H, Morneau, C, Payette, S, Richard, P, Robitaille, A, Saucier, J, Sirois, L, Thiffault, E \& Brisson, J 2009, 'Écologie forestière', in Ordre des ingénieurs forestiers, Manuel de foresterie, 2nd edn, Éditions Multimondes, Québec, pp. 167-319.

Gray, DH \& Sotir RB 1996, Biotechnical and Soil Bioengineering Slope Stabilization: A Practical Guide for Erosion Control, John Wiley \& Sons, Ltd. 
Haigh, MJ 1977, 'The use of erosion pins in the study of slope evolution', British Geomorphological Research Group Technical Bulletin, vol. 18, pp. 31-49.

Haigh, MJ \& Gentcheva-Kostadinova, S 2002, 'Ecological erosion control on coal-spoil banks: an evaluation', Ecological Engineering, vol. 18, no. 3, pp. 371-377.

Hansen, EA \& Baker, JB 1979, 'Biomass and nutrient removal in short rotation intensively cultured plantations', Proceedings: Impact of intensive harvesting on forest nutrient cycling, State University of New York, College of Environmental Science and Forestry, pp. 130-151.

Harper, K, Boudreault, C, DeGrandpré, L, Drapeau, P, Gauthier, S \& Bergeron, Y 2003, 'Structure, composition, and diversity of old-growth black spruce boreal forest of the Clay Belt region in Quebec and Ontario', Environmental Reviews, vol. 11, no. S1, pp. S79-S98.

Hoomehr, S 2012, 'Hydrology, Soil Erosion and Climate Interactions on Low Compaction Steep-Sloped Reclaimed Sites in the Southern Appalachian Coal Fields, Tennessee', University of Tennessee, viewed 16 November 2015, http://trace.tennessee.edu/cgi/ viewcontent.cgi?article $=2446 \&$ context=utk_graddiss

Jassal, RS, Black, TA, Arevalo, C, Jones, H, Bhatti, JS \& Sidders, D 2013, 'Carbon sequestration and water use of a young hybrid poplar plantation in north-central Alberta', Biomass and Bioenergy, vol. 56, pp. 323-333.

Jonasson, S 1983, 'The point intercept method for non-destructive estimation of biomass', Phytocoenologia, vol. 11, pp. 385-388.

Kittredge, J 1948, Forest Influences, McGraw-Hill, New York.

Larchevêque, M, Desrochers, A \& Larocque, GR 2011a, 'Comparison of manure compost and mineral fertilizer for hybrid poplar plantation establishment on boreal heavy clay soils', Annals of Forest Science, vol. 68, no. 4, pp. 849-860.

Larchevêque, M, Maurel, M, Desrochers, A \& Larocque, GR 2011b, 'How does drought tolerance compare between two improved hybrids of balsam poplar and an unimproved native species?', Tree Physiology, vol. 31, no. 3, pp. 240-249.

Loughran, R 1989, 'The measurement of soil erosion', Progress in Physical Geography, vol. 13, no. 2, pp. 216-233.

Marino, PC \& Gross, KL 1998, 'Competitive effects of conspecific and herbaceous (weeds) plants on growth and branch architecture of Populus $\times$ euramericana', Canadian Journal of Forest Research, vol. 367, pp. 359-367.

Nilsson, U 1994, 'Development of growth and stand structure in Picea abies stands planted at different initial densities', Scandinavian Journal of Forest Research, vol. 9, pp. 135-142.

Pang, W, Crow, WT, Luc, JE, McSorley, R, Giblin-Davis, RM \& Kenworthy, KE 2011, 'Comparison of Water Displacement and WinRHIZO Software for Plant Root Parameter Assessment', Plant Disease, vol. 95, no. 10, pp. 1308-1310.

Pierret, A, Moran, CJ, McLachlan, CB \& Kirby, JM 2000, 'Measurement of root length density in intact samples using x-radiography and image analysis', Image Analysis \& Stereology Impact Factor, vol. 19, pp. 145-149.

Pohl, M, Alig, D, Körner, C \& Rixen, C 2009, 'Higher plant diversity enhances soil stability in disturbed alpine ecosystems', Plant and Soil, vol. 324, pp. 91-102.

Reubens, B, Poesen, J, Danjon, F, Geudens, G \& Muys, B 2007, 'The role of fine and coarse roots in shallow slope stability and soil erosion control with a focus on root system architecture: a review', Trees, vol. 21, pp. 385-402.

Scholes, RJ \& Archer, SR 1997, 'Tree-grass interactions in savannas', Annual Review of Ecology and Systematics, vol. 28, pp. 517-544.

Shock, CC, Feibert, EBG, Saunders, LD \& Seddigh, M 2002, 'Initial Growth of Irrigated Hybrid Poplar Decreased by Ground Covers', Western Journal of Applied Forestry, vol. 17, no. 2, pp. 61-65.

Snowdon, P, Raison, J, Keith, H, Ritson, P, Grierson, P, Adams, M, Montagu, K, Bi, H, Burrows, W \& Eamus, D 2002, Protocol for sampling tree and stand biomass, Australian Greenhouse Office.

Spitz, K \& Trudinger, J 2008, Mining and the environment: from ore to metal, Taylor \& F.

Stanturf, J, Van Oosten, C, Netzer, D, Coleman, M \& Portwood, C 2001, 'Ecology and silviculture of poplar plantations', in Poplar culture in North America, pp. 153-2006.

Stokes, A, Norris, JE, Van Beek, LPH, Bogaard, T, Mickovski, SB, Jenner, A, Di lorio, A, Glasgow, G \& Keynes, M 2008, 'How vegetation reinforces soil on slopes', in Slope stability and erosion control: ecotechnological solutions, Springer, pp. 65-118.

Strong, T \& Hansen, E 1993, 'Hybrid poplar spacing/productivity relations in short rotation intensive culture plantations', Biomass and Bioenergy, vol. 4, pp. 255-261.

Styczen, M \& Morgan, R 1995, 'Engineering properties of vegetation', in Slope stabilization and erosion control: a bioengineering approach, Springer, pp. 5-58. 